\title{
Role of solidarity in social inclusion of children with emotional and behavioral disorders
}

\section{Karel Červenka}

\begin{abstract}
This paper is focused on educational inclusion of children with emotional and behavioral disorders. The objective aims to emphasize the importance of the social and cultural dimensions of the process of inclusion (not only) in education, especially with regard to the specifics of the situation of these children. Using the role that solidarity plays in the process of inclusion we emphasize the importance of its informal aspect.
\end{abstract}

Keywords: social inclusion, educational inclusion, solidarity, behavioral and emotional difficulties, special education, stigmatization, intervention.

\section{Role solidarity v procesu sociálního začleňování dětí s poruchami emocí a chování}

\begin{abstract}
Abstrakt
Text je zaměřen na problematiku inkluze ve vzdělávání dětí s poruchami emocí. Cílem textu je zdůraznit význam sociální a kulturní dimenze procesu inkluze (nejen) ve vzdèlávání, zejména s ohledem na specifika situace těchto dětí. Prostřednictvím role, kterou má solidarita v rámci procesu inkluze, je zdůrazněna důležitost jeho neformální stránky.
\end{abstract}


Klíčová slova: sociální inkluze, inkluze ve vzdělávání, solidarita, porucha emocí a chování, stigmatizace, etopedie, intervence.

\section{Introduction}

Inclusion in the school environment is seen as an "unending process of increasing learning and participation for all students" and as "the ideal to which schools can aspire but which is never fully reached: (Booth \& Ainscow 2002, p. 3). One of the key features of inclusion is involvement, participation of students with so-called special educational needs, or, more precisely, there are obstacles between them and their education that must be overcome. The involvement means not only "learning alongside others" but also sharing and experiencing the learning process in cooperation with others, while participation means recognition and acceptance (ibid.).

In this paper I will deal with the issue of inclusion of children with emotional and behavioral disorders. It is especially in their case where the issue of full social acceptance by others comes into the foreground. Without full social acceptance we can hardly think of social inclusion, and therefore of inclusion in education.

\section{Definition of basic parameters of the educational issue}

First, we need to define the basic parameters of the educational issue to which this paper is devoted. This problem is social and educational inclusion of children with emotional and behavioral disorders.

The issue of education of children with emotional and behavioral disorders is in many ways different from the education of children with different types of disabilities (physical, mental). Although social life plays an important role in the education of any child (disabled or not), in children with emotional and behavioral disorders it is even more important.

One of the distinctive characteristics of the situation of children with emotional and behavioral disorders, according to Bower (1981, p. 115), is their inability to build and maintain satisfactory interpersonal relationships with peers, teachers, etc. However, this is only one of many consequences of the specific situations and experiences of the child, which we refer to as emotional and behavioral disorders.

Such a situation, which, among others, may be negatively reflected in the quality of interpersonal relationships of the child, can be understood as a specific barrier in the life's journey of the child. Vojtová (2008) characterizes the relationship of a child with emotional and behavioral disorders especially by low behavior stability (active social isolation, aggressive behavior, withdrawal) and negative relations towards others and 
self. The aforementioned symptoms often lead to conflicts and are reflected in the social sphere of the child's life, personality and experience. This in turn acts as an obstacle to the child's life, preventing the child from fully developing their individual potential and exploiting their talents (cf. Helus, 2004). The negative impact of this situation affects the perception of the child as well as the quality of their present life and the prospects of good quality of life in adulthood. The situation of emotional and behavioral disorders thus ultimately limits the life chances and opportunities of the child, not only with regard to social relations, but generally restricting their chance of fulfilling their needs (cf. Vojtová, 2008).

\section{Social dimension of emotional and behavioral disorders}

What we refer to as behavioral disorder is mostly perceived by others as a negative deviation from the norm (Pokorná, 1993), which usually carries a strongly negative social significance. From the perspective of other people, a behavioral disorder is not only a matter of practical implications (conflicting nature of relationships, aggressive behavior, self-harming, etc.), but it is often also a question of negative social status that the child acquires due to their behavior. This status affects external (and internal) identity of the child and also influences other people's expectations of the child. As a consequence, such a status also influences the behavior of others towards the child. The status of a problem child carries real consequences - such as exclusion from natural social structures (family, neighborhood, school) due to segregation in a corrective facility, etc.

The interdependence between the child's experience, his/her behavior and the environment was highlighted by Bandura (1977) who formulated the concept of reciprocal determinism. Bandura emphasizes the relationship of the interaction between the actor and his/her environment. Specifically, he considers the fact that behavior, personality factors (experience) of the actor and the environmental factors interact (determine one another reciprocally): consequences of preceding situations will soon become a causal factor in others. Therefore we cannot say what influences the current situation - the factors of the actor or of the people around. Bandura's (1977) reciprocal determinism significantly highlights the dynamics of the relationship between the individual and the environment and therefore its complexity.

This optic leads to the perception of emotional and behavioral disorders as a dynamic process rather than an unchanging state. It also leads to understanding of behavioral disorders as a product of interaction between the child and his/her surroundings rather than just a result of poor education or a personality defect. As part of intervention for children with emotional and behavioral disorders it is therefore necessary to take into account not only personality factors, but also factors of the social environment. 
This, of course, also affects the general issue of social inclusion of these children, towards which the intervention should be directed.

When we speak of social inclusion, and more specifically of inclusion in education, in the same breath we speak of the relationship between society and individuals. Successful inclusion means a situation where the actor perceives him/herself as a member of the community and is perceived in the same way by other members of the community. The measure of such membership can be described, for example, using the concept of solidarity.

According to Alexander (2006, p. 17), entitlement to solidarity from the members of the community is what is "obtained by previously excluded groups" in the process of inclusion. In other words, solidarity is something that community members are entitled to. Although solidarity plays a key role in the process of inclusion from this perspective, it is often neglected as one of its results (that confirms the inclusion process) in the usual thinking about inclusion in education. I discussed the role of solidarity in the process of social inclusion of children with emotional and behavioral disorders in an earlier text (Červenka, 2016) but here I will elaborate the issue in relation to social integration and inclusion in education more broadly.

\section{Inclusive culture of schools as the fundamental basis of inclusion in education}

As I have mentioned in the introduction, inclusion is understood as a process of "increasing learning and participation for all students" (Booth \& Ainscow, 2002, p. 3). However, we can also define inclusion negatively, i.e. by its opposite - through the concept of exclusion. This is how, incidentally, we once again touch upon a number of characteristics of behavioral disorders: These are "temporary or longer pressures which get in the way of full participation", which may be the consequences of "difficulties in relationships or with what is taught, as well as from feelings of not being valued. Inclusion is about minimizing all barriers in education for all students" (Booth \& Ainscow, 2002, p. 3).

In this text, however, I will not only deal with inclusion in education but also with the more general process of social inclusion. Both of these processes can be understood as interdependent and separating them from each other only makes sense for analytical reasons. I will focus here primarily on the social and cultural dimension of the process of inclusion in (but not limited to) education, because both of these areas help determine the goals, direction and give value and meaning to sub-steps of inclusive strategies in education. Another reason is that I will consider the issue of social inclusion and educational inclusion of children with emotional and behavioral disorders. In this specific target group of the study of behavioral disorders, the importance of social life is highlighted compared to other groups of children (with disabilities) due 
to a strong link between the phenomenon of emotional and behavioral disorders and the surrounding social environment.

To accurately grasp the role that solidarity may play in the process of inclusion in education we can use the Index for inclusion (Booth \& Ainscow, 2002), where the importance of solidarity can be sought in the characteristics of inclusive school culture. The area of inclusive cultures in school environment is referred to as one of the three areas of the Inclusion index: 1) producing inclusive policies, 2) evolving inclusive practices, and 3) creating inclusive cultures (cf. Fig. 1). The authors consider these areas as "necessary to the development of inclusion within a school" while "any plan for school change must pay attention to all of them" (ibid., p. 7-8).

\section{Figure 1}

Three levels of Index for inclusion (Booth \& Ainscow, 2002, p. 7)
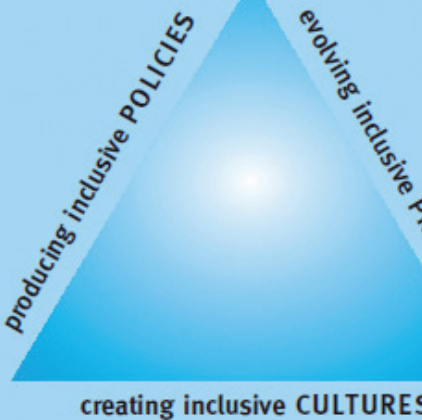

creating inclusive CULTURES

It is interesting that the authors consider the area of "creating inclusive cultures" as the fundamental basis of inclusion and symbolically placed it deliberately on the base of the triangle (see Fig. 1). They note that at different times "too little attention has been given to the potential for school cultures to support or undermine developments in teaching and learning" (Booth \& Ainscow, 2002, p. 8).

School culture also touches upon "the development of shared inclusive values and collaborative relationships."The objective is to create "a secure, accepting, collaborating, stimulating community, in which everyone is valued as the foundation for the highest achievements of all." Members of the community share inclusive values and pass them on to other and new members. "The principles and values, in inclusive school cultures, guide decisions about policies and moment to moment practice in classrooms, so that school development becomes a continuous process." (Booth \& Ainscow, 2002, p. 8).

What was just mentioned leads us to the consideration of how inclusion in education for children with emotional and behavioral disorders is dealt with, especially when 
taking into account the above characteristics and consequences of behavioral disorders. Let us examine more closely the relationship between solidarity and social inclusion.

\section{Solidarity as an indicator of the level of social integration: the role of perceived solidarity}

Issues affecting the continuum between social inclusion and exclusion reflects the nature of the relationship between the community and the actor or group of actors. Alexander $(2006$, p. 17) understands solidarity in close relation to the concept of inclusion and notes that "the concept of solidarity refers to subjective feelings associated with inclusion that individuals experienced in relation to members of their own social groups." Inclusion is the process, as mentioned above, through which marginalized or excluded actors or groups of actors become entitled to solidarity of the community. (ibid.)

For this text, the essential idea is that inclusion in the truest sense of the word means not only behavioral, formal or mechanical participation in community life but that such participation should be accompanied by felt solidarity. As an example, Alexander mentions the situation of the Jews in the context of medieval Western societies in which they lived and worked, but they were not included in the (true) sense. (Alexander, 2006)

Here we find points of contact with the inclusive school culture proclaimed by Booth and Ainscow (2002). Being included in the school environment should, in the light of Alexander's (2006) definition of inclusion, mean feeling solidarity with the members of the school community, feeling one is a member, rather than just having the right, chance and opportunity to be educated with other children in primary or middle school. Here I do not only mean children with disabilities but also children from ethnic or cultural minorities and children with a variety of other social or individual characteristics. Without felt solidarity, the situation would be closer to the one which corresponds to the integration process, whose leitmotif is the child's adaptation to the environment.

To further emphasize the differences between integration and inclusion I will use Alexander's (2006) definition of assimilation of ethnic and other groups that is inherently reminiscent in its nature to the integration process in education. Alexander highlights the deep paradoxes of assimilation, especially in the regard that it "often continues to stigmatize the characteristics of marginalized groups even after previously excluded persons are included and are allowed to become free"'. Alexander notes that for full inclusion, "the characteristics of marginalized groups must undergo a process of rethinking," in which case "pluralism does not mean abolishing differences, but rather highlighting their civil and public implications". (Alexander, 2006, p. 14) 


\section{Redefining stigmatized properties - Inclusion, solidarity and social acceptance}

Building on the previous paragraph, in the case of inclusion of children with behavioral disorders the objective is neither cancellation of their symptoms (aggression, emotional outbursts, depression, etc.), nor statutory limitation on the severity of their crimes. Rath$\mathrm{er}$, it is the acceptance of these manifestations as characteristics that are a manifestation of deeper (unfulfilled) child's needs (need for security, belonging, appreciation), which in themselves do not prevent acceptance of the child as a social personality.

Booth and Ainscow $(2002$, p. 3) note that inclusion begins by acknowledging the differences among students and that "the development of inclusive approaches to teaching and learning respect and build on such differences."

It should be understood that social environment typically responds to manifestations of emotional and behavioral disorders or problem behavior by social rejection. In connection with the phenomenon of stigmatization, Goffman (2003) pointed out that the stigmatized actor loses (at least partly) the full human status in the eyes of other people. This is done through exclusion of the stigmatized person from full social acceptance. People around tend to perceive the actor as an incomplete person, "as a polluted, devalued person". This often leads to a reduction of his/her life chances and opportunities (Goffman, 2003)

Social environment approaches the stigmatized person through the prism of his/ her stigma (of mental illness, crime, problem behavior), and tends to reduce his/her personality to the related characteristics. A number of characteristics of the stigmatized person is thus lost from the spotlight. Which is a shame for the intervention process, especially if we might use these characteristic to support the intervention (interests, skills, resources, social support).

The aforementioned redefinition of the stigmatized characteristics in the process of inclusion (not assimilation or integration) represents an approach that seeks to recover full humanity (including the status of solidarity) for these persons. In the context of special education we need to use the so-called soft-terminology (cf. Vojtová, 2008), which focuses on accurate labeling of special education phenomena by trying to separate the child's personality as a whole from the problematic characteristics and thus avoid their generalization on the whole personality of the child. The problem is not seen as a major, but as a secondary characteristic of the child ${ }^{1}$. Example: A child is not perceived as dyslexic, but as a child with dyslexia. The problem is not used to derive the identity of the child and the child's personality is not reduced to one, albeit significant, characteristic. At the same time, however, the existence of the problem is not denied.

\footnotetext{
Comp. with the concepts of master status and auxiliary status distinguished by Hughes (according to Becker, 1991). The master status leads to a generalization of certain characteristics on the whole personality of the actor while it prevails over its other characteristics, which become indistinct.
} 
In terms of inclusive intervention, this approach provides space for the perception of the individuality of the child in the wholeness of his/her personality, personality characteristics and the needs derived from them. The problem is seen through the prism of personality and needs of the child, rather than the child's personality being seen through the prism of the problem.

\section{Conclusion}

This text is not intended to comprehensively discuss the issue of social and educational inclusion of children with emotional and behavioral disorders but to emphasize the importance of social and cultural dimensions of this process due to the specifics of the situation of these children. In this regard, it is useful to use the above-mentioned concept of solidarity abundantly, as it opens a space for thinking in terms of social relations. It helps point out that inclusion in the true sense is not and cannot be only about the right to a common education for all children or the opportunities legislation creates and defines for them. These are formal expressions of solidarity. For inclusion in the true sense, the presence of informal, felt solidarity based on the existence of relationships between people is essential. Its symptoms include experience of social acceptance, which may be an incentive to full membership and participation in broader society for children with emotional and behavioral disorders. They often have the opportunity to gain such an experience within interventional relationship with educational professionals (child behavioral expert, psychologist, educator, teacher). For the child, such a relationship can play the role of an intervention means, but it may also represent the objective to restore the relationship with the broader society (cf. Červenka, 2016).

\section{References}

Alexander, J. C. (2006). Ústřední solidarita, etnická okrajová skupina a sociální diferenciace. In Marada, R. (Ed.). Etnická různost a občanská jednota. Brno: Centrum pro studium demokracie a kultury (CDK).

Bandura, A. (1977). Social Learning Theory. London, Prentice_hall International, Inc.

Becker, H., S. (1991). Outsiders: studies in the sociology of deviance ([New ed.]). New York: Free Press. Booth, T. \& Ainscow, M. (2002). Index for Inclusion: Developing learning and participation in schools. Brisol, CSIE.

Bower, E. M. (1981). Early identification of emotionally handicapped children in school ( $3^{\text {rd }}$ ed.). Springfield, Ill.: C. C. Thomas.

Červenka, K. (2016). Sud, který nemá dno? Potřeby dètí s poruchami emocí a chování očima výchovných profesionálů. Brno: Masarykova univerzita.

Goffman, E. (2003). Stigma: poznámky k problému zvládání narušené identity. Praha: Sociologické nakladatelství. 
Helus, Z. (2004). Dítě v osobnostním pojetí: obrat k dítěti jako výzva a úkol pro učitele i rodiče. Praha: Portál.

Pokorná, V. (1993). Poruchy chování u dětí a jejich náprava. Praha: Karolinum.

Vojtová, V. (2008). Kapitoly z etopedie I ( $2^{\text {nd }}$ revised ed.). Brno: Masarykova univerzita.

\section{Contact:}

Karel Červenka

Katedra speciální pedagogiky PdF MU

Poříčí 9, Brno, Czech Republic

E-mail: charel@mail.muni.cz 